\title{
Boring bacteria?
}

Some microorganisms can bore into carbonate rock, such as limestone, an activity that has major implications for coastal erosion and the destruction of coral reefs. However, the mechanism by which these bacteria bore was previously unknown. Garcia-Pichel and colleagues now report on a novel system that allows experimental investigation of bacterial boring, and find that the bacteria can locally readjust the $\mathrm{Ca}^{2+}$ concentration via P-type ATPase transporters, leading to boring.

The process of boring had been assumed to rely on manipulation of the equilibrium of the dissolution reaction $\mathrm{CaCO}_{3}(\mathrm{~s})+\mathrm{H}^{+} \leftrightarrow \mathrm{Ca}^{2+}+\mathrm{HCO}_{3}^{-}$, but how the bacteria affect this equilibrium was previously unclear, in part owing to a lack of cultured bacterial strains that can drill into carbonate rock. The authors isolated a strain of cyanobacteria, known as BC008, that can bore into calcite chips and used it to test various hypotheses of how boring occurs.

The authors initially ruled out the hypothesis that boring occurs through local acidification due to spatial or temporal restriction of photosynthesis (which would lead to a shift in respiration, resulting in acid production), as BC008 did not appear to require a dark period in order to bore, nor did it display a difference in photosynthetic rates along a cross section of an actively boring culture. The authors then tested whether the bacteria alter the equilibrium of the dissolution reaction by decreasing the local $\mathrm{Ca}^{2+}$ concentration.

Laser scanning confocal fluorescence microscopy revealed a clear decrease in the $\mathrm{Ca}^{2+}$ concentration at the boring front and an increase in the $\mathrm{Ca}^{2+}$ concentration at the entrance of the borehole on the surface of the calcite chip, indicating that active transport of $\mathrm{Ca}^{2+}$ occurs internally through the bacterial population.

To identify a mechanism whereby the bacteria could alter $\mathrm{Ca}^{2+}$ concentration, the authors looked for genes encoding $\mathrm{Ca}^{2+}$-transporting P-type ATPases in the BC008 genome. Interestingly, the genes they identified were upregulated in boring cultures. Furthermore, treatment with inhibitors of P-type ATPases drastically reduced boring efficiency. The authors propose that the transporters pump $\mathrm{Ca}^{2+}$ out of the cell at the borehole entrance to create an intracellular gradient that is transmitted through the culture and ultimately causes a local decrease in $\mathrm{Ca}^{2+}$ concentration at the bore site, leading to the solubilization

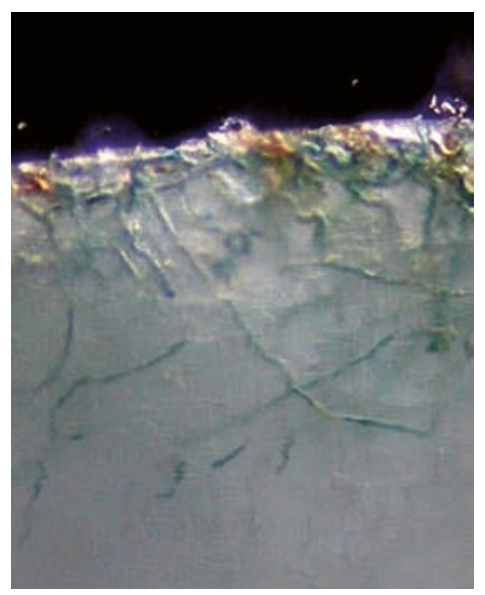

Blue-green filaments of cyanobacteria boring into a chip of crystalline calcite, detected using a dissecting microscope. Image courtesy of E. Ramírez-Reinat, Arizona State University, Tempe, USA.

of carbonate. The exact mechanism and distribution of the transporters remain to be clarified.

As human activity causes increased global $\mathrm{CO}_{2}$ levels, the saturation levels of oceanic carbonate will decrease, which will lower the energy costs of boring, leading to an increase in boring activity by bacteria, especially in shallow waters. This will impact coral reef stability and industrial processes such as bivalve aquaculture.

Joanna E. Huddleston

ORIGINAL RESEARCH PAPER Garcia-Pichel, F. et al. Microbial excavation of solid carbonates powered by P-type ATPase-mediated transcellular $\mathrm{Ca}^{2+}$ transport. Proc. Natl Acad. Sci. USA 29 Nov 2010 (doi:10.1073/pnas.1011884108) 